\title{
Role of Metacognitive and Social Strategies in Learning a Foreign Language: A Case Study of Indian and Chilean students
}

\author{
Dr. Ranjeeva Ranjan ${ }^{1}$, Dr. Andrew Philominraj ${ }^{2}$ \\ ${ }^{1}$ University of Hyderabad, Hyderabad, India \\ ${ }^{2}$ Universidad Católica del Maule, Chile
}

\begin{abstract}
The language learning strategies has emerged as a new field of research in the language pedagogy. In the last forty five years there have been lot of debate over defining, classifying and developing a theoretical framework for the language learning strategies (LLS). This also seems true because there has been a paradigm shift in the role of the learners who are now seen as active collaborators in the knowledge creation. In the present paper, the researchers would like to investigate the role of metacognitive and social strategies employed by the learners in two different classroom settings; one in learning Spanish as foreign language in India and the other in learning English as foreign language in Chile. After providing a little explanation of theoretical framework, the researchers would try to present a comparative study between the these two types of learning strategies employed by the Chilean students and Indian students while learning English and Spanish as foreign language respectively. The researchers have carried out a qualitative research and based on the response provided by the learners they have attempted to see the similarities and dissimilarities between the learning approaches in the aforementioned learning environments. By doing so, they have made an effort to throw light at some of the problems faced by the students while learning a foreign language in non-native context.
\end{abstract}

Keywords- foreign language, leraning strategies, metacognitive strategies, social strategies.

\section{THE FIRST USE OF THIS TERM AND ITS DEFINITION}

The first use of the term strategies in the context of language learning appeared in the fundamental work of $\mathrm{J}$. Rubin (1975) with the title "What the" Good Language Learner "can teach us". This article is considered a work of great influence in the field of research related to language learning strategies. In this seminal article, the individual variation of learning and differential success among students was questioned. In this paper, the author also examined in detail the strategies employed by successful language learners and how these learning strategies can be taught to less successful students. Rubin gave a series of activities carried out by successful language students such as practice, memorization, guessing etc.

Language learning strategies have been defined in a number of ways by various scholars in the field of second language acquisition and foreign language learning. According to the Cambridge Dictionary, the strategy is defined as "a detailed plan to achieve success in situations such as war, politics, business, industry or sport, or the ability to plan for such situations". Using the same definition in the case of language learning, it can be said that strategies are plans to achieve success in the learning process. The strategies which the students use while processing new information and performing tasks have been identified and described by researchers in several ways. For instance Rubin (1975) referred to strategies as "techniques or devices which a learner may use to acquire knowledge". Oxford R. (1990) points out that the learning strategies can be considered as steps taken by the students themselves to facilitate their own learning. Another scholar in this field, Anna Uhl Chamot (2004), mentions about the presence of element of consciousness in the learning strategies that the learners use to accomplish a learning goal.

From the psychological perspectives, Oxford points out that second or foreign language learning strategies can be defined as "an action plan, behaviour, step, or technique that a student uses, with a certain degree of awareness, to improve their progress in developing skills in a second or foreign language". She adds that such strategies can facilitate "the internalization, storage, recovery and use of the new language and are tools for greater student autonomy".

It is clear that all language learners use learning strategies consciously or unconsciously when processing new idea and carrying out tasks in the language classroom. The classroom provides surroundings in which students are expected to get new information and deal with difficult 
tasks and it is natural to see their attempts to find the quickest means to do them comfortably. These attempts and eagerness to do and complete the tasks given by the teacher in the classroom are referred to as strategies.

\section{CLASSIFICATION}

One of the most important challenges in the field of language learning strategies is their taxonomies. Researchers always face problem of sorting and categorizing the strategies employed by learners due to several reasons. Some of them are:

$>$ Non-existence of a theoretical framework of classification

$>$ Unobservable strategies

$>$ The individual difference in learning

$>$ The different individual variables such as age, gender, nationalities etc.

$>$ Environmental factors

Hsiao \& Oxford (2002) underlines that despite previous research on the existence and application of learning strategies, it is very difficult to classify the strategies employed by the students and it is always open for further deliberations.

The most accepted classification of strategies is that of Oxford. Oxford divides language learning strategies into two main classes, direct and indirect, which are subdivided into 6 groups. Direct strategies are those that "require mental processing of language" and, therefore, "directly involve the target language" (Oxford, 1990, p.37). Indirect strategies are called "indirect" because they support and manage language learning without (in many cases) directly involving the target language". In the first category, she put three types which are memory, cognitive and compensation strategies and in the second one, she includes three other types which are metacognitive, affective and social.

\section{METACOGNITIVE AND SOCIAL STRATEGIES}

Metacognition has been defined as knowledge and understanding of one's own thinking. Metacognitive means "beyond" the cognitive. So theoretically metacognitive strategies are those which are beyond the cognitive strategies and they involve the internal processing of the learning behaviors. Metacognitive strategies include the planning, organization, evaluation and monitoring of students' own language learning, for example, organizing the time to learn, checking one's progress and analyzing one's mistakes and trying not to do them again. This category is extensively employed in the field of research on second/foreign language learning. Almost all researchers in the field of learning strategies attach great importance to this category as each learner, to be successful, has to regulate and plan the internal processes of learning a foreign language.

On the other hand, social strategies refer to how students interact with others while learning any language and target culture. Social strategies include, among other things, asking someone to speak slowly, practice with others and show interest in learning about the culture of countries of the target language.

These two types of strategies are chosen as the first category indicates the internal processing of the information and thereby shows the potential of metacognition in learning a foreign language. The second one is chosen so as to have a holistic view of how the learners interact with their partners and others in two different learning settings with different cultural background and how these social strategies of learning a foreign language change with the surroundings.

\section{RESEARCH FINDINGS AND ANALYSIS}

The average use of language learning strategies was measured using the questionnaire SILL ${ }^{1}$. The survey was conducted the survey to the university students in India and Chile. The students at both the places are studying the respective foreign language as full time post graduate course. On the basis of the response, the researchers have tried to analyze the data quantitatively. The SILL is measured on a likert scale of 5 , where 1 is the least used and 5 being the most used. On the basis of the response provided by the learners of these two foreign languages, the researchers would like to share the results. Firstly, we would like to share the average use of the six categories of strategies and then we would elaborate more on two types which are metacognitive and social. The TABLE 1 that indicates the average use of language learning strategies for the six different types of learning strategies.

Table.1: Average use of language learning strategies

\begin{tabular}{|c|c|c|}
\hline Type of Strategy & $\begin{array}{c}\text { Average } \\
\text { Indian }^{\mathbf{1}}\end{array}$ & $\begin{array}{c}\text { Average } \\
\text { Chilean }^{2}\end{array}$ \\
\hline Memory & 2.85 & 2.65 \\
\hline Cognitive & 3.24 & 3.52 \\
\hline Compensation & 3.33 & 3.42 \\
\hline Metacognitive & 3.59 & 4.16 \\
\hline Affective & 2.98 & 2.99 \\
\hline Social & 3.62 & 3.68 \\
\hline
\end{tabular}

${ }^{1}$ Indian students learning Spanish as foreign language

${ }^{2}$ Chilean students learning English as foreign language The above result has been obtained through the quantitative approach of quantifying the data. If one

${ }^{1}$ SILL- Strategy Inventory for Language Learning 
compares the two results, one can find that the most used strategies are metacognitive strategies for Chilean students and social strategies for Indian students. The use of social strategies is almost the same for both the groups (3.68 for Chilean and 3.62 for Indian students). The average use of affective strategies is almost the same for both the group of students (2.99 for Chilean and 2.98 for Indian students). From the TABLE 1, it is also evident that the average use of the other two categories of strategies (social and compensation) is also almost the same for these two groups of students. The metacognitive strategies are more frequently employed by the Chilean students than the Indian which underlines the fact that they have more metacognitive control and exercises this metacognition in their learning process to enhance their learning experiences. The above result also suggests that the Indian students use the memory strategies more often than their Chilean counterparts while learning Spanish as foreign language whereas for the cognitive strategies the Chilean students can be seen using these strategies more frequently.

\section{COMPARISON OF METACOGNITIVE AND SOCIAL STRATEGIES}

Below are two tables obtained from the response of the survey conducted to the university students in India and Chile.

Table.2: Metacognitive strategies

\begin{tabular}{|l|l|l|l|}
\hline $\begin{array}{c}\text { SILL } \\
\text { No. }\end{array}$ & \multicolumn{1}{|c|}{ Part D- Metacognitive } & India $^{\mathbf{1}}$ & Chile $^{\mathbf{2}}$ \\
\hline 32 & $\begin{array}{l}\text { I pay attention when someone } \\
\text { is speaking Spanish/English } \\
\text { (S/E) }\end{array}$ & 4.16 & 4.67 \\
\hline 38 & $\begin{array}{l}\text { I think about my progress in } \\
\text { learning S/E. }\end{array}$ & 3.95 & 4.33 \\
\hline 33 & $\begin{array}{l}\text { I try to find out how to be a } \\
\text { better learner of S/E }\end{array}$ & 3.79 & 4.92 \\
\hline 31 & $\begin{array}{l}\text { I notice my S/E mistakes and } \\
\text { use that to help me do better. }\end{array}$ & 3.74 & 4.08 \\
\hline 35 & $\begin{array}{l}\text { I look for people I can talk to } \\
\text { in S/E. }\end{array}$ & 3.56 & 2.92 \\
\hline 37 & $\begin{array}{l}\text { I have clear goals for } \\
\text { improving my S/E skills. }\end{array}$ & 3.42 & 3.75 \\
\hline 30 & $\begin{array}{l}\text { I try to find as many ways as I } \\
\text { can to use my S/E }\end{array}$ & 3.34 & 4.17 \\
\hline 34 & $\begin{array}{l}\text { I plan my schedule so I have } \\
\text { enough time to study S/E. }\end{array}$ & 3.19 & 4.08 \\
\hline 36 & $\begin{array}{l}\text { I look for opportunities to } \\
\text { read as much as possible in } \\
\text { S/E. }\end{array}$ & 3.19 & 4.50 \\
\hline
\end{tabular}

${ }^{1}$ Indian students learning Spanish as foreign language

${ }^{2}$ Chilean students learning English as foreign language

The TABLE 2 indicates the 9 questions which were part of the survey belonging to the metacognitive strategies of language learning from SILL which was used for this research. If one takes a look at the list, one can find out that the Chilean students attach more importance to these strategies as it is evident from the mean of the score. Except for one strategy numbered 35, the Chilean learners have reported using more all other metacognitive strategies listed above than their Indian counterparts. Three metacognitive strategies which show the most difference between these two types of students are trying to find out how to be a better learner, planning the schedule to have enough time and looking for opportunities for reading. These strategies demonstrate that the Chilean students always try to use their metacognitive skills in their learning trajectory through their internal mechanisms which are manifested in some of the strategies mentioned in the TABLE 2. They also dominate in planning and looking for opportunities to demonstrate their learning skills and thereby enhancing the whole learning process. The only strategy where the average use is greater for Indian students is looking for people to talk to in the foreign language. Another strategy is looking for different ways to use the language learnt. Here again the Chilean students surpass their counterparts.

Now let's look at another category of strategies which belongs to social. As it is evident from the name itself, these strategies refer to the interactions and practising the foreign language with peers and the natives.

Table.3: Social strategies

\begin{tabular}{|l|l|l|l|}
\hline $\begin{array}{c}\text { SILL } \\
\text { No. }\end{array}$ & \multicolumn{1}{|c|}{ Part F- Social } & India $^{\mathbf{1}}$ & Chile $^{\mathbf{2}}$ \\
\hline 50 & $\begin{array}{l}\text { I try to learn about the } \\
\text { culture of S/E speakers. }\end{array}$ & 3.82 & 3.67 \\
\hline 49 & I ask questions in S/E. & 3.79 & 2.50 \\
\hline 45 & $\begin{array}{l}\text { If I don't understand } \\
\text { something, I ask to slow } \\
\text { down or repeat. }\end{array}$ & 3.73 & 4.33 \\
\hline 46 & $\begin{array}{l}\text { I ask S/E speakers to correct } \\
\text { me when I talk. }\end{array}$ & 3.56 & 3.00 \\
\hline 47 & $\begin{array}{l}\text { I practice my S/E with other } \\
\text { students. }\end{array}$ & 3.48 & 4.58 \\
\hline 48 & $\begin{array}{l}\text { I ask for help from S/E } \\
\text { speakers. }\end{array}$ & 3.34 & 4.00 \\
\hline
\end{tabular}

${ }^{1}$ Indian students learning Spanish as foreign language

${ }^{2}$ Chilean students learning English as foreign language

The TABLE 3 shows that the Indian students have high average use in three items and the Chilean have scored more in the other three. The Indian students use the social strategies like learning about the culture, as king questions in foreign language and asking to correct themselves while talking. The Indian students who are learning Spanish as foreign language consist of a heterogeneous 
group and they come to language classroom from very different cultural areas, with different education systems and a variety of native languages. The response of foreign language learners in Chile show that they are more open to their peer students for practice and they either ask for help from native speakers of the language or they ask to slow down if they don't understand anything . So the TABLE 3 indicates that the Indian students show more interest in learning about the culture of target language countries where as the Chileans are more inclined in asking someone to speak slowly or practice the target language with others.

\section{CONCLUSION}

The main idea of this paper was to reflect upon the two types of language learning strategies which the students use in the aforementioned learning environment while learning a foreign language in a non native context. One has to consider the individual variation of processing the new information obtained in the language classroom. All students are not similar and many of them do not know how to activate mental functions called learning strategies and as a consequence they cannot learn in a better way, resulting in minimal learning. That is why it is proposed that the introduction and training of the strategies in the FL class should be carried out in order to have the most fruitful and effective result. We also have to take into consideration the fact that the students of this century are equipped with a lot of information and with the arrival of new technology; they are already well informed about various aspects of the language. They need a guide, a facilitator, a mentor who can help them acquire the various skills in a better way. In this sense, strategies can play an important role and act as a tool to facilitate the learning process of Spanish language in the Indian context. Modern language learning in the 21st century should allow and educate students in such a way that they develop autonomous thinking and work as a responsible social agent. Therefore, in this type of situation, it is even more important to consider the philosophy of knowledge construction with the active participation of students and to reflect on a dialogical model between the two protagonists. In this sense, the learning strategies can provide an important tool which the students can employ for facilitating their learning process.

\section{REFERENCES}

[1] Bhatnagar, Y.C. (2000). Second Language Pedagogy in India, New Delhi: Ajanta Book International Publication.

[2] Cohen, A. \& Macaro, E. (2007). Language Learner Strategies: 30 Years of Research and Practice Author. Oxford: Oxford University Press
[3] Cohen, L., Manion, L., \& Morrison, K. (2007). Research Methods in Education. Londres, Inglaterra: Routledge/ Falmer.

[4] Cohen, A. D. (2012). Strategies: The interface of styles, strategies and motivation on tasks. In Mercer, S., Ryan, S. and Williams, M. (eds.) Psychology for Language Learning: Insights from Research, Theory and Practice (pp.136-151). Houndmills: Palgrave Macmillan.

[5] Cohen, A. D. \& Griffiths, C. (2015). Revisiting LLS research 40 years later. TESOL Quarterly,49(2), 414-429.

[6] Ellis, Rod. (2010). SLA Research and Language Teaching, Delhi: Oxford University Press.

[7] Griffiths, Carol. (2013). The strategy factor in successful language learning. Bristol: Multilingual Matters.

[8] Griffiths, C. (2015). Language learning strategy instruction.Journal of Applied Linguistics (GALA) 29, 36-49.

[9] Griffiths, C., \& Inceçay, G. (2016). New directions in language learning strategy research: Engaging with the Complexity of Strategy Use. In Gkonou, C., Tatzl, D. \& Mercer, S. (eds.) New Directions in Language Learning Psychology. Berlin: Springer.

[10] Griffiths, C. \& Oxford, R.L. (2014). The twentyfirst-century landscape of language learning strategies: Introduction to this special issue. In Oxford, R. L. \& Griffiths, C. (eds.), Language learning strategy research in the twenty-first century. Special issue, System: International Journal of Educational Technology and Applied Linguistics, 43, $1-10$.

[11] Hsiao, T. \& Oxford, R.L. (2002). Comparing theories of language learning strategies: A confirmatory factor analysis. Modern Language Journal, 86(3), 368-383.

[12] O'Malley, J. and A.Chamot (1990). Language learning strategies. Cambridge: Cambridge University Press.

[13] O'Malley, M., \& Chamot, A. (2012). Learning Strategies in Second Language Acquisition. UK: Cambridge University Press

[14] Oxford, R. (1990). Language learning strategies: what every teacher should know. New York: Newbury House.

[15] Oxford, R. L. (1990). Strategy Inventory for Language Learning (SILL). In R. L. Oxford, Language learning strategies: What every teacher should know (pp. 283-300). Boston: Heinle \& Heinle / Thoms on Learning.

[16] Oxford, R. L. (1989). Use of language learning strategies: A synthesis of studies with implications for strategy training. System, 17(2), 235-247. 
[17] Oxford, R. L. (1990). Using and learning languages through simulations, Part II. Simulation and Gaming: An International Journal of Theory, Design, and Research, 21(1), 73-74.

[18] Oxford, R. L. (1999). Relationships between second language learning strategies and language proficiency in the context of learner autonomy and self-regulation. Revista Canaria de Estudios Ingleses, 38, 108-126.

[19] Saxena, Rajiv (2008). La Enseñanza de Español como Lengua Extranjera en la India: Desarrollo y Desafíos. New Delhi.

[20] Stern H.H. (1983) Fundamental Concepts of Language Learning, London: Oxford University Press, Second Edition 1984. 